\title{
Tinjuan Yuridis Terhadap Pasal 28 Ayat (2) UU ITE (Sudi Kasus : I Gede Ari Astina Alias Jerinx atau JRX )
}

\author{
Ryadh Mega Putera ${ }^{1}$, Krista Yitawati ${ }^{2}$ \\ ${ }^{1}$ Mahasiswa Fakultas Hukum, Universitas Merdeka Madiun, Jl. SerayuNo.79, Madiun, 63133 \\ E-mail: - \\ ${ }^{2}$ Fakultas Hukum, Universitas Merdeka Madiun, Jl. SerayuNo.79, Madiun, 63133 \\ E-mail:krista@unmer-madiun.ac.id
}

\begin{abstract}
Article 28 paragraph (2) of the ITE Law is one of the articles that regulate the spread of hatred in social media. The provisions of that article still lead to a multi-faceted understanding of the sense of hatred that the passage refers to. This study aims to find out about the regulation of hatred according to positive law and the arrangement of the article in the future. This study uses normative legal research methods that are sourced from the legislation. Hate-related arrangements are regulated in some legislation, but in particular, a sense of hatred in social media is set in Article 28 paragraph (2) of the ITE Law. The use of Article 28 the case of I Gede Ari Astina better known as Jerinx and also the difficulty in solving cases deemed to have violated this article. The provisions of the article still need improvement to further limit the actions of other users, while for Article 28 paragraph (2) there is no change.
\end{abstract}

Keywords - : Hatred; Article 28 paragraph (2; UU ITE.

\section{PENDAHULUAN}

Pasal 28 ayat (2) UU ITE merupakan salah satu peraturan dalam hukum positif Indonesia yang dipergunakan untuk membatasi perbuatan-perbuatan yang melanggar di media sosial terkait dengan rasa kebencian dan juga unsur suku, agama, ras, dan antar golongan (SARA). Pasal 28 ayat (2) UU ITE berbunyi, 'setiap orang dengan sengaja dan tanpa hak menyebarkan informasi yang ditujukan untuk menimbulkan rasa kebencian atau permusuhan individu dan/atau kelompok masyarakat tertentu berdasarkan atas suku, agama, ras, dan antargolongan (SARA). Terkait pemahaman dari kebencian itu sendiri, dalam pasal tersebut tidak ada pemahaman yang cukup jelas. Oleh karena itu, terkait dengan hal tersebut, dalam Pasal 156 KUHP lebih mengarah ke perbuatan yang menyatakan permusuhan (vijanschap) yaitu, perbuatan yang menyatakan dengan ucapan yang isinya dipandang oleh umum sebagai memusuhi suatu golongan penduduk Indonesia. Perbuatan menyatakan kebencian (haat) adalah berupa perbuatan menyatakan dengan ucapan yang isinya dipandang atau dinilai oleh masyarakat umum sebagai membenci terhadap suatu golongan penduduk Indonesia. Perbuatan yang isinya dipandang oleh umum menyatakan ucapan 3 yang menghina, merendahkan, melecehkan terhadap suatu golongan penduduk Indonesia. ${ }^{1}$

Di Indonesia sendiri banyak terjadi kasus penyebaran informasi bermuatan ujaran kebencian berdasarkan atas suku, agama, ras, dan antargolongan. Berdasarkan catatan dari ICJR (Institute for Criminal Justice Reform), di tahun 2017 terdapat 46 kasus yang dilaporkan ke kepolisian dan 27 kasus yang dibawa ke persidangan dengan menggunakan ketentuan Pasal 28 ayat (2) UU ITE, sedangkan di tahun 2018 terdapat 41 kasus yang dilaporkan ke kepolisian dan 35 kasus yang dibawa ke persidangan dengan menggunakan Pasal 28 ayat (2) UU ITE. ${ }^{2}$

Pada dasarnya, Pasal 28 ayat (2) UU ITE ini bertujuan untuk mencegah terjadinya permusuhan dan perpecahan berbasis suku, agama, ras, dan antargolongan dikarenakan isu SARA merupakan isu yang sangat sensitif di masyarakat sehingga adanya informasi yang bersifat provokatif dan mengandung kebencian berkaitan dengan hal tersebut dapat menimbulkan permusuhan. Pada faktanya, adanya sebuah kasus yang dianggap telah melanggar ketentuan dari pasal tersebut yaitu kasus ujaran kebencian di media sosial Instagram oleh I Gede Ari Astina alias Jerinx. Jerinx dianggap telah melakukan penyebaran rasa kebencian di media sosial. Melalui akun media sosialnya dimana Jerinx memberikan komentar di akun instagramnya yang berisi tentang “ IDI KACUNG WHO”. Komentar Jerinx dianggap menyebarkan ujaran kebencian serta pencemaran nama baik. Akibat dari penyebaran komentar tersebut, pihak IDI Bali menganggap bahwa institusinya di nodai dan menuntut Jerinx untuk dipenjara atas dugaan ujaran kebencian. Dampak dari perbuatan tersebut, Jerinx dianggap telah melakukan penyebaran rasa kebencian di media sosial yang menyebabkan dirinya Jerinx disangka dengan Pasal 28 ayat (2) Jo Pasal 45A ayat (2). Berdasarkan ketentuan pasal tersebut, Jerinx telah melakukan penyebaran rasa kebencian di media sosial yang mengandung unsur SARA. Terkait dengan hal tersebut, keterangan dari Jerinx sendiri mengatakan bahwa tujuan tersebut adalah Justru karena saya berharap akan ada reaksi atau tanggapan. Harapannya mendapat respon, karena sebelumnya beberapa kali mengajak IDI untuk berdiskusi

\footnotetext{
${ }^{1}$ Adami Chazawi, 2016, Hukum Pidana Positif Penghinaan, Cetakan II Edisi Revisi, Media Nusa Creative, Malang, (selanjutnya disingkat Adami Chazawi I), h. 199.

2 Anggara Suwahju, ‘Menakar Makna “Antargolongan” Dalam Pasal 28 (2) UU ITE’ (Beritagar.id, 2019) . accessed 20 November 2020
} 
langsung, tapi tidak pernah ditanggapi. Jadi saya terpaksa memakai diksi yang agak sedikit nyeleneh dengan harapan agar direspon. Kata kacung sendiri Sengaja diapakai menurut Jerinx IDI adalah pelayan. Maksudnya yang melayani. ${ }^{3}$ Pemahaman yang multitafsir terkait ketentuan Pasal 28 ayat (2) UU ITE tersebut terhadap penggunaanya pada kasus Jerinx yang dapat dikatakan mampu bertentangan dengan hak kebebasan berpendapat dan berekspresi di media sosial. Ketentuan Pasal 28 ayat (2) UU ITE pada faktanya masih memerlukan penjelasan terkait maksud dari rasa kebencian tersebut dan juga terkait dengan perbuatan-perbuatan yang di anggap melanggar ketentuan pasal tersebut. Hal tersebut berguna untuk mencegah adanya pelanggaran terkait hak kebebasan berpendapat di media sosial dan juga untuk tidak menimbulkan kesan multitafsir atau norma kabur terhadapan ketentuan pasal tersebut di masa yang akan datang. Hal tersebut berdasarkan fakta yang terjadi banyaknya perbuatan-perbuatan yang belum tentu dapat dianggap melanggar peraturan perundang-undangan. Selain itu juga perlunya batasan-batasan terkait perbuatan di media sosial. Hal ini karena setiap perbuatan di media sosial, memungkinkan untuk memberikan pengaruh bagi opini publik yang berkembang di masyarakat. ${ }^{4}$

Berdasarkan fenomena tersebut, maka dalam kesempatan kali ini penulis ingin memaparkan sebuah karya tulis yang dilandasi beberapa rumusan masalah sebagai batasan bahasan yang diantaranya sebagai berikut:

1. Apakah makna kata "kebencian" menurut ketentuan hukum di Indonesia?

2. Bagaimanakah sebaiknya cara meminimalisir pengaturan ketentuan Pasal 28 ayat (2) UU ITE di masa yang akan datang ?

\section{METODE PENELITIAN}

Penelitian hukum ini menggunakan penelitian hukum normatif dimana hukum dikonsepkan sebagai apa yang tertulis dalam peraturan perundang-undangan (law in books) atau hukum dikonsepkan sebagai kaidah atau norma yang merupakan patokan berperilaku manusia yang dianggap pantas. dengan pendekatan perundang-undangan dan pendekatan konseptual. sedangkan menurut jenisnya adalah penelitian terhadap data sekunder. Teknik pengumpulan bahan hukum yang mendukung dan berkaitan dengan pemaparan penulisan hukum ini adalah dengan studi kepustakaan (library researche) dan dianalisis dengan menggunakan analisis kualitatif serta ditafsirkan dengan metode interpretasi sistematis dan interpretasi gramatikal. Data yang digunakan dalam penelitian ini meliputi dua sumber yaitu data primer dan data sekunder. Data primer diperoleh dengan menganalisis peraturan perundang-undangan yang meliputi Undang - Undang Informasi dan Transaksi Elektronik Nomor 19 Tahun 2016 tentang Perubahan Atas Undang - Undang Informasi dan Transaksi Elektronik Nomor 11 Tahun 2008. Data sekunder diperoleh dari sejumlah keterangan melalui bahan dokumen, literatur, dan hasil penelitian lainnya.

\section{III.ANALISIS DAN PEMBAHASAN}

\section{A. Pengaturan Rasa Kebencian sesuai dengan Ketentuan Hukum di Indonesia}

Pengaturan terkait rasa kebencian dalam hukum positif di Indonesia diatur dalam beberapa peraturan perundang-undangan. Diantaranya yaitu, Pasal 156 Kitab Undang-Undang Hukum Pidana (KUHP), Pasal 20 ayat (2) Undang-Undang Nomor 12 Tahun 2005 tentang Pengesahan Kovenan Internasional tentang Hak-Hak Sipil dan Politik, Pasal 16 juncto Pasal 1 angka 3 Undang-Undang Nomor 40 Tahun 2008 tentang Penghapusan Diskriminasi Ras dan Etnis, Pasal 28 juncto 45 ayat (2) UndangUndang Nomor 19 Tahun 2016 tentang Perubahan Atas Undang-Undang Nomor 11 Tahun 2008 tentang Informasi dan Transaksi Elektronik, dan ada juga peraturan-peraturan lainnya yang terkait. Pemahaman terkait rasa kebencian dalam Pasal 156 KUHP $^{5}$, disebutkan bahwa perbuatan tersebut dilakukan dengan ucapan yang berisi kata-kata atau kalimat tertentu. Oleh karena dinyatakan dengan ucapan, maka disebut menyatakan perasaan dengan lisan. Isinya pernyataan perasaan tersebut dinyatakan dalam tiga macam yaitu :

a. Pernyataan,

b. Mengenai,

c. Permusuhan,

d. Kebencian, dan

e. Penghinaan terhadap golongan penduduk Indonesia. ${ }^{6}$

Kriteria suatu ucapan agar dapat dipandang oleh umum sebagai pernyataan permusuhan, kebencian, atau menghina terhadap suatu atau beberapa golongan penduduk Indonesia yang dapat dijadikan pegangan adalah pada nilai-nilai moral, tata susila dan kepatutan dalam pergaulan hidup bermasyarakat sebagai suatu bangsa yaitu bangsa Indonesia. ${ }^{7}$

Pemahaman terkait rasa kebencian dalam Pasal 28 ayat (2) UU ITE tidak ada penjelasan lebih lanjut. Hal ini yang menimbulkan adanya pemahaman yang multitafsir dan banyaknya pandangan dan pendapat dari banyak pihak terkait dengan

\footnotetext{
3 Tribunnews.com, jerinx-bongkar-alasan-menulis-idi-kacung-who-sengaja-memakai-diksi-nyeleh-ini-tujuannya”, $28 \quad$ Oktober 2020. https://www.tribunnews.com/seleb/2020/10/28/jerinx-bongkar-alasan-menulis-idi-kacung-who-sengaja-memakai-diksi-nyeleh-ini-tujuannya. (diakses 20 November 2020)

${ }^{4}$ Tim Pusat Humas Kementerian Perdagangan RI, 2014, Panduan Optimalisasi Media Sosial Untuk Kementerian Perdagangan RI, Cetakan I, Kementerian Perdagangan RI, Jakarta Pusat, h. 26-27.

${ }^{5}$ Moeljatno, 2012, Kitab Undang-Udang Hukum Pidana, Bumi Aksara, Jakarta, h. 59.

${ }^{6}$ Adami Chazawi I, op.cit, h. 199

${ }^{7}$ Adami Chazawi I, op.cit, h. 200.
} 
kebencian yang dimaksud dan juga ketentuan pasal tersebut. Pendapat pertama, mengatakan merupakan suatu tindak pidana formil. Selesainya tindak pidana terletak pada selesainya perbuatan. Alasannya dalam rumusan pasal, tidak secara tegas melarang menimbulkan akibat tertentu. Hal tersebut terletak pada frasa "ditujukan untuk" dalam rumusan pasal tersebut, yang bisa diartikan bahwa perbuatan menyebarkan informasi ditujukan agar timbul rasa kebencian. Berdasarkan penjelasan tersebut, membutuhkan pembuktian, bahwa perbuatan menyebarkan tersebut bertujuan untuk menimbulkan rasa benci. Caranya dengan melogikan wujud dari perbuatan tersebut menurut sifat dan keadaannya dapat menimbulkan kebencian antar golongan dan sebagainya yang disadari dan dikehendaki si pembuat. ${ }^{8}$

Pendapat kedua, perbuatan tersebut termasuk tindak pidana materiil. Tindak pidana selesai sempurna jika akibat adanya rasa kebencian atau permusuhan antar kelompok masyarakat telah timbul. Alasan pendapat kedua adalah dalam hubungannya dengan pembuktian. Perasaan permusuhan dan kebencian, hanya ada dalam hati. Tidak bisa diketahui dan dibuktikan sebelum ada wujud nyata dari tindakan yang menggambarkan rasa ketidak senangan atau permusuhan tersebut. Dalam hal ini, jika perbuatan telah terwujud sementara akibat tidak timbul, kejadian itu termasuk percobaan, pelakunya sudah dapat dipidana. ${ }^{9}$

Berdasarkan penjelasan tersebut, terkait ketentuan Pasal 28 ayat (2) UU ITE masih menimbulkan pemahaman yang multitafsir. Namun pada faktanya, ketentuan dari pasal tersebut telah dipergunakan dalam menyelesaikan banyak kasus yang melanggar isi pasal tersebut diantaranya yaitu, kasus Sandy Hartono, Alexander Aan, Muhamad Rokhisun. Ketiga kasus tersebut, memiliki latarbelakang yang berbeda-beda dan sudah mendapatkan putusan akhir. Pada pelaksanaan penggunaan pasal tersebut di lingkungan peradilan, para penegak hukum terkhusus hakim, harus menggunakan penafsiran hukum untuk memberikan pemahaman bahwa suatu perbuatan telah melanggar pasal tersebut. Penafsiran itu sendiri, menurut Profesor Mr. D. Simons, syarat pokok untuk melakukan penafsiran terhadap suatu peraturan perundang-undangan adalah bahwa peraturan tersebut itu harus ditafsirkan berdasarkan peraturan perundang-undangan itu sendiri. Dalam menguraikan penafsiran tersebut, tidak boleh mencari bahan-bahan di luar peraturan tersebut. Pada faktanya, meskipun suatu peraturan perundang-undangan itu telah dibentuk dengan mempergunakan katakata dan istilah yang tegas, akan tetapi masih ada kemungkinan untuk memberikan penafsiran, bahkan dapat menimbulkan keraguan.11Berdasarkan dari ketiga kasus tersebut, dapat disimpulkan bahwa perbuatan yang dapat dikategorikan telah melanggar ketentuan Pasal 28 ayat (2) UU ITE yaitu,

a. adanya pihak-pihak yang merasa dirugikan oleh perbuatan seseorang atau sekelompok orang yang berkaitan dengan unsur SARA,

b. Perbuatan tersebut memuat gambar-gambar tentang orang-orang yang disucikan dalam suatu agama yang bertentangan dengan gambar aslinya,

c. Membuat tulisan yang menjelek-jelekan isi dari kitab suci suatu agama yang berbeda dengan ajaran agama tersebut atau,

d. Menyebarluaskan hal-hal yang bersifat pribadi yang bertentangan atau melanggar norma-norma kesopanan dan kesusilaan,

e. Perbuatan yang dilakukan mengandung unsur SARA dan dilakukan di media sosial. ${ }^{10}$

Terkait dengan perbuatan yang melanggar ketentuan Pasal 28 ayat (2) UU ITE belakangan ini yang sedang terjadi dan masih dalam proses peradilan yaitu kasus Jerinx. Jerinx dianggap telah melakukan penyebaran rasa kebencian di media sosial Instagram dengan menyebarkan komentar yang berujung kebencian tentang “IDI KACUNG WHO” ,. Berdasarkan keterangan dari saksi ahli bahwa perbuatan Jerinx Ahli hukum pidana Universitas Trisakti Abdul Fickar Hadjar menilai penetapan drummer Superman is Dead (SID) I Gede Astina alias Jerinx menjadi tersangka kasus ujaran kebencian 'IDI Kacung WHO' dinilai berlebihan.

Berikut kronologi kasus Jerinx SID terkait ujaran 'IDI kacung WHO'.

\section{13 Juni 2020: Mengunggah Komentar Berisi Tuduhan Terhadap IDI}

Pada tanggal 13 Juni 2020, Jerinx mengunggah foto yang berisi kalimat tuduhan bahwa IDI dan rumah sakit menjadi adalah 'kacung' WHO lantaran kebijakan rapid test yang diberlakukan untuk para ibu hamil. Berikut tulisan unggahan Jerinx di akun Instagram pribadinya @jrxsid.

"Gara-gara bangga jadi kacung WHO, IDI dan RS seenaknya mewajibkan semua orang yang akan melahirkan dites COVID19. Sudah banyak bukti jika hasil tes sering ngawur kenapa dipaksakan? Kalau hasil tes-nya bikin stres dan menyebabkan kematian pada ibu atau bayinya, siapa yang tanggung jawab?" tulis Jerinx.

Tak sampai di situ, dalam kolom keterangannya, Jerinx juga meminta agar IDI dibubarkan.

\footnotetext{
${ }^{8}$ Adam Chazawi dan Ardi Ferdian, 2011, Tindak Pidana Informasi \& Transaksi Elektronik Penyerangan Terhadap Kepentingan Hukum Pemanfaatan Teknologi Informasi dan Transaksi Elektronik, Bayumedia Publishing, Malang, (selanjutnya disingkat Adami Chazawi II), h. 132.

10 Fransiskus Sebastian Situmorang, Ida Bagus Surya Dharmajaya, I Made Walesa Putra, Tinjauan Yuridis Terhadap Ketentuan Pasal 28 Ayat (2) UU Informasi dan Transaksi Elektronik, terdapat dalam https://ojs.unud.ac.id/index.php/kerthawicara/article/view/35324/21319, diakses terakhir tanggal 26 November 2020 pada pukul 10.20 Wib.
} 
"BUBARKAN IDI! Saya gak akan berhenti menyerang kalian @ikatandokterindonesia sampai ada penjelasan perihal ini! Rakyat sedang diadu domba dengan IDI/RS? TIDAK. IDI \& RS yg mengadu diri mereka sendiri dengan hak-hak rakyat," tulis Jerinx.

\section{16 Juni 2020: IDI Bali Melaporkan Jerinx ke Polisi}

Akibat unggahan kontroversial tersebut, pada 16 Juni 2020, IDI Bali lantas melaporkan Jerinx ke Polda Bali dengan tuduhan pencemaran nama baik lantaran Jerinx menyebut IDI sebagai 'kacung' WHO. Selain itu, IDI Bali juga melaporkan Jerinx atas dugaan ujaran kebencian.

\section{3 Agustus 2020: Jerinx Mangkir dari Panggilan Polisi}

Atas laporan yang diberikan oleh IDI Bali, Polda Bali kemudian melayangkan surat panggilan ke Jerinx pada Senin, (3/8/2020). Namun, menurut Ditreskrimsus Polda Bali, Kombes Yuliar Kus Nugroho, Jerinx tidak memenuhi panggilan polisi lantaran sibuk.

\section{5 Agustus 2020: Jerinx Penuhi Panggilan Polisi}

Setelah sempat mangkir dari panggilan polisi, Polda Bali melayangkan kembali surat panggilan kedua kepada Jerinx yang dijadwalkan pada Kamis (6/8). Rabu (5/8) Jerinx datang ke Polda Bali untuk memenuhi panggilan polisi dan menjalani pemeriksaan terkait kasus tersebut. Terkait permasalahan ini, Kasubag Humas Polda Bali, Kombes Syamsi menyebut pihaknya sudah memeriksa sejumlah saksi termasuk para saksi ahli. Dalam pertemuannya itu, Jerinx terlihat memakai kaos bertuliskan 'Tolak Rapid Test' tanpa menggunakan masker.

\section{12 Agustus 2020: Jerinx Ditahan}

Jerinx ditahan oleh Polda Bali dan kini resmi berstatus tersangka atas kasus ujaran kebencian dan pencemaran nama baik yang dilaporkan oleh IDI Bali. Setelah kebar Jerinx ditahan, publik dikejutkan dengan beredarnya sebuah video yang memperlihatkan Jerinx menggunakan baju tahanan oranye dengan tangan diborgol di dalam tahanan viral di media sosial. ${ }^{11}$

\section{Pengaturan Ketentuan Pasal 28 Ayat (2) UU ITE di Masa yang Akan Datang}

Ketentuan Pasal 28 ayat (2) UU ITE, pada masa sekarang telah dipergunakan dalam menyelesaikan kasus-kasus yang terjadi di masyarakat. Namun yang terkait dengan penggunaannya, menimbulkan permasalahan tersendiri di masyarakat. Hal ini terbukti dengan banyaknya perbuatan yang mengandung unsur SARA dan juga kebencian di media sosial namun tidak bisa ditindak. Selain itu, banyaknya perbuatan yang sebenarnya tidak melanggar ketentuan pasal tersebut, dianggap telah melanggar pasal tersebut. Hal ini menyebabkan banyaknya pihak-pihak yang melakukan aksi saling lapor ke pihak kepolisian terkait perbuatan-perbuatan tersebut yang menyebabkan pihak kepolisian sendiri kesusahan.

Ketentuan Pasal 28 ayat (2) UU ITE pada masa ini dianggap menyebabkan adanya pembatasan yang tidak jelas terkait dengan hak kebebasan berpendapat dan berekspresi di media sosial. ${ }^{12}$ Hal tersebut melihat banyaknya perbuatan-perbuatan yang dianggap telah melanggar ketentuan pasal tersebut. Oleh karena itu, di masa yang akan datang diharapkan bahwa penggunaan pasal tersebut dalam kehidupan bermasyrakat lebih diperjelas batasanbatasannya. Pasal 28 ayat (2) UU ITE terbaru, masih menimbulkan pemahaman yang multitafsir terkait maksud dari ketentuan pasal tersebut. Hal tersbut berkaitan dengan tidak adanya penjelasan lebih lanjut terkait hal-hal yang masih membutuhkan penjelasan sepertinya rasa kebencian yang dimaksud, bentuk penyebaran informasi dan hal lainnya. Adanya perbedaan pendapat terkait dengan perbuatan yang dapat dikatakan telah melanggar ketentuan pasal tersebut. Hal tersebut terkait dengan tindak pidana formil dan materiil dari yang perbuatan dimaksudkan oleh pasal tersebut. Tindak pidana formil jika dikaitkan dengan pasal tersebut, tidak secara tegas melarang menimbulkan akibat tertentu dari perbuatan tersebut. Selain itu, perbuatan tersebut memerlukan pembuktian bahwa perbuatan tersebut bertujuan untuk menimbulkan rasa kebencian, dan untuk tindak pidana materiil jika dikaitkan dengan pasal tersebut, berkaitan dengan pembuktian itu sendiri. Perbuatan tersebut telah menimbulkan akibat yang wujudnya nyata, karena terkait dengan rasa kebencian dan lainnya merupakan sesuatu hal yang hanya ada dalam diri manusia. ${ }^{13}$

Terkait dengan ketentuan Pasal 28 ayat (2) UU ITE di masa yang akan datang, diharapkan mampu memenuhi dan sesuai dengan harapan dari masyarakat. Hal tersebut agar masyarakat mengetahui batasan-batasan dalam menggunakan media sosial dan agar masyarakat mengetahui perbuatan-perbuatan yang dapat dianggap telah melanggar peraturan. Diperlukannya juga pemberian pemahaman dan pengertian terkait rasa kebencian dan unsur-unsur SARA.

Usulan-usulan lainnya terkait UU ITE dan juga Pasal 28 ayat (2) yaitu, perlunya dibuat bab khusus untuk perbuatanperbuatan yang mengandung pelanggaran unsur SARA di media sosial. Kedepannya akan lebih baik dalam pembaharuan di masa yang akan datang menggunakan Surat Edaran Kepolisian terkait rasa kebencian. Dalam surat edaran tersebut, diberikan pemahaman terkait bentuk-bentuk ujaran kebencian yang berasal dari KUHP dan juga aturan-aturan lainnya di luar KUHP. Adapun bentukbentuknya yaitu,

a. Penghinaan,

b. Pencemaran nama baik,

c. Penistaan,

\footnotetext{
${ }^{11}$ suara.com," kronologi-kasus-idi-kacung-who-hingga-jerinx-ditahan", 13 Agustus 2020,

<https://www.suara.com/news/2020/08/13/201249/kronologi-kasus-idi-kacung-who-hingga-jerinx-ditahan?page=all>[ diaksees 1 Desember 2020 ]

${ }^{12}$ Ifdhal Kasim, 2001, Hak Sipil dan Politik, Esai-Esai Pilihan, ELSAM, Jakarta, h.12.

${ }^{13}$ Adam Chazawi II, op.cit, h. $132-133$.
} 
Website : http://yustisia.unmermadiun.ac.id/index.php/yustisia

d. Perbuatan tidak menyenangkan,

e. Memprovokasi,

f. Menghasut,

g. Menyebarkan berita bohong.

Semua perbuatan tersebut berkemungkinan menimbulkan diskriminasi, kekerasan, penghilangan nyawa, dan juga konflik sosial. Ada juga dalam surat edaran tersebut media yang dapat dimungkinkan dipergunakan untuk melakukan ujaran kebencian yaitu,

a. Dalam orasi kegiatan kampanya,

b. Spanduk atau banner,

c. Jejaring media sosial,

d. Penyampaian pendapat di media sosial,

e. Ceramah keagamaan,

f. Media massa atau cetak atau elektronik,

g. Pamflet. ${ }^{14}$

Kebijakan penanggulangan kejahatan atau yang biasa dikenal dengan istilah "politik kriminal" dapat meliputi ruang lingkup yang cukup luas. Bahwa menurut G. Peter Hoefnagels, upaya penanggulangan kejahatan dapat ditempuh dengan tiga cara yaitu $:^{15}$

a. Penerapan hukum pidana (criminal law application);

b. Pencegahan tanpa pidana (prevention without punishment), dan

a. Mempengaruhi pandangan masyarakat mengenai kejahatan dan pemidanaan lewat mass media (influencing views of society on crime and punishment/mass media)

Dengan demikian, upaya penanggulangan kejahatan secara garis besar dapat dibagi dua, yaitu lewat jalur "penal” (hukum pidana) dan lewat jalur "nonpenal" (bukan/di luar hukum pidana). Namun secara kasar dapatlah dibedakan, bahwa upaya penanggulangan kejahatan lewat "jalur penal" lebih menitik beratkan pada sifat "repressive" (penindasan/pemberantasan/penumpasan) sesudah kejahatan terjadi, sedangkan jalur "nonpenal” lebih menitikberatkan pada sifat "preventive" (pencegahan/penangkalan/pengendalian) sebelum kejahatan terjadi. Dikatakan sebagai perbedaan secara kasar, karena tindakan represif pada hakikatnya juga dapat dilihat sebagai tindakan preventif dalam arti luas. Mengingat upaya penanggulangan kejahatan lewat jalur "nonpenal" lebih bersifat tindakan pencegahan untuk terjadinya kejahatan, maka sasaran 96 Barda Nawawi Arief, Bunga Rampai Kebijakan Hukum Pidana (Perkembangan Penyusunan Konsep KUHP Baru), Kencana Prenada Media Group, Jakarta, 2008, hlm. 3988 utamanya adalah menangani faktor-faktor kondusif penyebab terjadinya kejahatan. Faktor-faktor kondusif itu antara lain, berpusat pada masalah-masalah atau kondisi-kondisi sosial secara langsung atau tidak langsung dapat menimbulkan atau menumbuh suburkan kejahatan. Dengan demikian, dilihat dari sudut politik criminal secara makro dan global, maka upaya-upaya nonpenal menduduki posisi kunci dan staregis dari keseluruhan upaya politik kriminal, posisi kunci dan strategis dalam menanggulangi sebab-sebab dan kondisi-kondisi yang menimbulkan kejahatan. Dijelaskan dalam bukunya Prof. Dr. Barda Nawawi Arief yang berjudul Bunga Rampai Kebijakan Hukum Pidana, bahwa penyebab utama dari kejahatan di banyak negara termasuk di Indonesia ialah ketimpangan sosial, diskriminasi rasial dan diskriminasi nasional, standar hidup yang rendah, pengangguran dan kebutahurufan (kebodohan) di antara golongan besar penduduk, maka terdapat beberapa aspek sosial yang diidentifikasikan sebagai faktor kondusif penyebab terjadinya kejahatan, yaitu antara lain : ${ }^{16}$

a. Kemiskinan, pengangguran, kebutahurufan (kebodohan), ketiadaan/kekurangan perumahan yang layak dan sistem pendidikan serta latihan yang tidak cocok/serasi;

b. Meningkatnya jumlah penduduk yang tidak mempunyai prospek (harapan) karena proses inetgrasi sosial juga karena memburuknya ketimpanganketimpangan sosial;

c. Mengendurnya ikatan sosial dan keluarga;

d. Keadaan-keadaan/kondisi yang menyulitkan bagi orang-orang yang berimigrasi ke kota-kota atau ke negara-negara lain;

e. Rusaknya atau hancurnya identitas budaya asli, yang bersamaan dengan adanya rasisme dan diskriminasi menyebabkan kerugian/kelemahan di bidang sosial, kesejahteraan dan lingkungan pekerjaaan;

f. Menurun atau mundurnyaa (kualitas) lingkungan perkotaan yang mendorong peningkatan kejahatan dan berkurangnya (tidak cukupnya) pelayanan bagi tempat-tempat fasilitas lingkungan/bertetangga;

g. Kesulitan-kesulitan bagi orang-orang dalam masyarakat modern untuk berin tegrasi sebagaimana mestinya di dalam lingkungan masyarakatnya, di lingkungan keluarga/familinya, tempat pekerjaannya atau di lingkungan sekolahnya;

h. Penyalahgunaan alkohol, obat bius dan lain-lain yang pemakaiannya juga diperluas karena faktor-faktor yang disebut diatas;

i. Meluasnya aktivitas kejahatan teroganisasi, khususnya perdagangan obat bius dan penadahan barang-barang curian;

\footnotetext{
${ }^{14}$ Adami Chazawi I, op,cit, h. 199.

${ }^{15}$ Barda Nawawi Arief, Bunga Rampai Kebijakan Hukum Pidana (Perkembangan Penyusunan Konsep KUHP Baru), Kencana Prenada Media Group, Jakarta, 2008, hlm. 39

${ }^{16}$ Ibid., hlm. 43
} 
j. Dorongan-dorongan (khususnya oleh mass media) mengenai ide-ide dan sikap-sikap yang mengarah pada tindakan kekerasan, ketidaksamaan (hak) atau sikap-sikap tidak toleran (intoleransi).

Maraknya tindakan kejahatan berupa perbuatan ujaran kebencian yang terjadi di Indonesia saat ini membuat rusaknya atau hancurnya identitas budaya asli, yang bersamaan dengan adanya rasisme dan diskriminasi yang menyebabkan kerugian/kelemahan baik di bidang sosial, kesejahteraan dan lingkungan, hal tersebut dikarenakan kesulitan bagi orang-orang dalam masyarakat modern untuk berintegrasi sebagaimana mestinya di dalam lingkungan masyarakatnya, di lingkungan keluarga/familinya, tempat pekerjaannya maupun di dunia maya sekalipun. Kebijakan upaya non penal harus dijadikan strategi dasar dan utama dalam menanggulangi ujaran kebencian, maka semua pihak baik masyarakat, peemrintah, maupun penegak hukum harus terlibat karena dalam upaya non penal terdapat menggarap kesehatan jiwa masyarakat, maka jiwa masyarakat harus dikelola, disehatkan agar dalam menggunakan media sosial masyarakat 90 tidak mengarah terhadap perbuatan pidana termasuk perbuatan ujaran kebencian.98 Beberapa masalah dan kondisi sosial yang dapat merupakan faktor kondusif penyebab timbulnya kejahatan ujaran kebencian, jelas merupakan masalah yang tidak dapat diatasi semata-mata dengan "penal". Disinilah keterbatasan jalur "penal" dan oleh karena itu, harus ditunjang oleh jalur "non penal". Maka dari itu penulis ingin menjelaskan mengenai kebijakan non penal yang ideal (tepat) untuk meminimilasir tindak pidana ujaran kebencian di Indonesia dengan menggunakan beberapa pendekatan seperti pendekatan sosial dan pendekatan agama

\section{$>$ Pendekatan sosial}

Kebijakan sosial pada dasarnya adalah kebijakan atau upaya-upaya rasional untuk mencapai kesejahteraan masyarakat. Jadi identik dengan kebijakan atau perencanaan pembangunan meliputi berbagai aspek yang cukup luas dari pembangunan. Penanganan atau kebijakan berbagai aspek pembangunan ini sangat penting, karena pembangunan itu sendiri dapat bersifat "kriminogen" apabila pembangunan itu : ${ }^{17}$

a. Tidak direncanakan secara rasional, atau direncanakan secara timpang, tidak memadai/tidak seimbang;

b. Mengabaikan nilai-nilai kultural dan moral; dan

c. Tidak mencakup strategi perlindungan masyarakat yang menyeluruh/integral.

Salah satu aspek kebijakan sosial yang kiranya patut mendapatkan perhatian ialah penggarapan masalah kesehatan jiwa masyarakat (social hygiene), baik secara individual sebagai anggota masyarakat maupun kesehatan/kesejahteraan keluarga (termasuk masalah kesejahteraan anak dan remaja), serta masyarakat luas pada umumnya. Penggarapan masalah "mental health", "national health", dan "child welfare" ini pun dikemukakan dalam skema Hoefnagels sebagai salah satu jalur "prevention (of crime) without punishment"(jalur non penal). Prof. Sudarto juga mengemukakan bahwa "kegiatan karang taruna, kegiatan pramuka, dan penggarapan kesehatan jiwa masyarakat dengan pendidikan agama" merupakan upaya-upaya non penal dalam mencegah dan menanggulangi kejahatan. Penggarapan kesehatan masyarakat lingkungan sosial yang sehat (sebagai salah satu upaya nonpenal dalam strategi politik criminal), tidak hanya harus berorientasi pada pendekatan kesehatan rohani/mental tetapi juga berorientasi pada pendekatan inilai-nilai pandangan hidup dan dentitas budaya nasional. Pentingnya pendekatan identitas budaya nasional dikarenakan, bahwa salah satu faktor kondusif terjadinya kejahatan ialah faktor "the destruction of original cultural identities". ${ }^{18}$

\section{$>$ Pendekatan agama}

Melalui pendekatan agama, Majelis Ulama Indonesia menerbitkan Fatwa MUI Nomor 24 tahun 2017 tentang Hukum dan Pedoman Bermuamalah melalui Media Sosial. Dalam fatwa MUI tersebut tercantum beberapa hal yang diharamkan bagi umat Islam dalam penggunaan media sosial, misalnya seperti setiap Muslim yang bermuamalah melalui media sosial diharamkan melakukan gibah (membicarakan keburukan atau aib orang lain), fitnah, namimah (adu domba), dan penyebaran permusuhan. ${ }^{19}$

Berdasarkan terdapatnya masalah dan kondisi sosial yang merupakan faktor kondusif penyebab timbulnya kejahatan ujaran kebencian, yang jelas merupakan masalah yang tidak dapat diatasi semata-mata dengan penal sehingga dengan adanya upayaupaya non penal melalui pendekatan sosial, pendekatan politik maupun pendekatan agama, pemerintah, aparat penegak hukum dan masyarakat bekerjasama dan bersinergi dalam meminimilasir dan mencegah faktor-faktor terjadinya perbuatan ujaran kebencian agar tidak terus menerus terjadi suatu perbuatan ujaran kebencian yang dapat merusak dan memecah belah persatuan bangsa Indonesia. Melalui dilaksanakannya kebijakan-kebijakan sosial yang dilakukan oleh pemerintah yakni terus membangun kerja sama dengan tokohtokoh masyarakat dan agama, termasuk sosialiasi di lembaga pendidikan. Penyuluhan terkait informasi larangan ujaran kebencian yang dilakukan secara lebih masif kepada masyarakat dapat menumbuhkan dan meningkatkan kesadaran hukum masyarakat serta budaya masyarakat, maka hal ini penting untuk dilakukan agar dapat menekan turunnya potensi terjadinya tindak pidana ujaran kebencian terutama di media sosial

\section{IV.KESIMPULAN DAN SARAN}

\footnotetext{
${ }^{17}$ Barda Nawawi Arief, op.cit., hlm. 44

${ }^{18}$ Ibid., hlm. 47

${ }^{19}$. https://www.kominfo.go.id/content/detail/9829/mui-keluarkan-fatwa-bermuamalah-dimedia-sosial/0/sorotan_media diakses terakhir tanggal 20 November 2020 pukul $18.10 \mathrm{Wib}$.
} 
a. Pengaturan tentang rasa kebencian diatur dalam beberapa peraturan perundang-undangan dalam hukum positif, secara khusus diatur dalam Pasal 28 ayat (2) Undang - Undang Informasi dan Transaksi Elektronik Nomor 11 Tahun 2008. Pasal 28 ayat (2) UU ITE yang mengatur secara khusus terkait rasa kebencian masih menimbulkan pemahaman yang multitafsir atau norma kabur. Hal tersebut melihat kenyataan yang ada di masyarakat bahwa dalam menangani kasus-kasus yang berkaitan dengan kebencian di media sosial masih sulit untuk diatasi.

b. Pengaturan tentang rasa kebencian pada amandemen UU ITE terbaru yaitu Undang - Undang Informasi dan Transaksi Elektronik Nomor 19 Tahun 2016 tentang Perubahan Atas Undang - Undang Informasi dan Transaksi Elektronik Nomor 11 Tahun 2008. Dalam UU ITE terbaru tidak ada perubahan terbaru terkait dengan rasa kebencian yang menyebabkan tetap adanya pemahaman yang multitafsir karena dalam UU ITE terbaru tersebut lebih berfokus kepada sanksi dan perubahan pasal lainnya diluar Pasal 28 ayat (2).

c. Kembali ke kasus I Gede Ari Astina Alias Jerinx di dakwa dengan pasal 28 ayat ( 2 ) jo pasal 45 A ayat ( 2 ) Undang Undang Informasi Dan Transaksi Elektronik menurut saya ada kejanggalan dimana isi dari pasal tersebut bertemakan SARA. Apakah IDI ini adalah golongan yang dikualifikasi berbasis dan bertemakan SARA ?, dilihat dari Jerinx sendiri mengunggah pernyataan tersebut hanya merasa kesal dan hanya ingin mengajak diskusi pihak IDI serta tidak ada niat untuk melakukan ujaran kebencian. Pasal ini juga seperti pasal karet dan kurang jelas dalam kasus ini. Ketika kita ingin ber ekspresi malah di bui.

\section{DAFTAR PUSTAKA}

\section{A. Buku}

Chazawi, Adami, 2016, Hukum Pidana Positif Penghinaan, Media Nusa Creative, Malang.

Chazawi, Adami dan Ardi Ferdian, 2011, Tindak Pidana Informasi \& Transaksi Elektronik Penyerangan Terhadap Kepentingan 14 Hukum Pemanfaatan Teknologi Informasi dan Transaksi Elektronik, Bayumedia Publishing, Malang.

fdhal Kasim, 2001, Hak Sipil dan Politik, Esai-Esai Pilihan, ELSAM, Jakarta,h.12.

Barda Nawawi Arief, Bunga Rampai Kebijakan Hukum Pidana (Perkembangan Penyusunan Konsep KUHP Baru), Kencana Prenada Media Group, Jakarta, 2008, hlm. 39

Moeljatno, 2012, Kitab Undang-Udang Hukum Pidana, Bumi Aksara, Jakarta, h. 59.

Tim Pusat Humas Kementerian Perdagangan RI, 2014, Panduan Optimalisasi Media Sosial Untuk Kementerian Perdagangan RI, Cetakan I, Kementerian Perdagangan RI, Jakarta Pusat.

\section{B. Jurnal}

Adam Chazawi II, op.cit. hal 132 - 133.

Adami Chazawi I, op,cit hal 199.

Ibid,.hal 132-133.

Adami Chazawi I, op.cit.hal 200

Ibid., hlm. 43

Ibid., hlm. 43

Barda Nawawi Arief, op.cit., hlm. 44

\section{Peraturan Perundang-undangan}

Undang-Undang Nomor 11 Tahun 2008 Tentang Informasi dan Transaksi Elektronik.

Undang-Undang Nomor 19 Tahun 2016 Tentang Perubahan Atas Undang-Undang Nomor 11 Tahun 2008 Tentang Informasi Dan Transaksi Elektronik Kitab Undang-undang Hukum Pidana.

\section{Website}

Anggara Suwahju, 'Menakar Makna "Antargolongan” Dalam Pasal 28 (2) UU ITE’ (Beritagar.id, 2019) . diakses 20 November 2020

Tribunnews.com”, jerinx-bongkar-alasan-menulis-idi-kacung-who-sengaja-memakai-diksi-nyeleh-ini-tujuannya”, $28 \quad$ Oktober 2020. https://www.tribunnews.com/seleb/2020/10/28/jerinx-bongkar-alasan-menulis-idi-kacung-who-sengaja-memakai-diksi-nyeleh-ini-tujuannya. (diakses 20 November 2020)

cnnindonesia.com," pakar-proses-hukum-jerinx-soal-idi-kacung-who-lebay", 13 Agustus 2020 24https://www.cnnindonesia.com/nasional/20200813094805-12535192/pakar-proses-hukum-jerinx-soal-idi-kacung-who-lebay.( diakses 21 November 2020)

https://www.kominfo.go.id/content/detail/9829/mui-keluarkan-fatwa-bermuamalah-dimedia-sosial/0/sorotan_media diakses terakhir tanggal 20 November 2020 pukul $18.10 \mathrm{Wib}$.

Garjito, Dany," kronologi-kasus-idi-kacung-who-hingga-jerinx-ditahan”. 2020,.https://www.suara.com/news/2020/08/13/201249/kronologi-kasus-idi-kacungwho-hingga-jerinx-ditahan?page=all

Fransiskus Sebastian Situmorang, Ida Bagus Surya Dharmajaya, I Made Walesa Putra, Tinjauan Yuridis Terhadap Ketentuan Pasal 28 Ayat (2) UU Informasi dan Transaksi Elektronik, terdapat dalam https://ojs.unud.ac.id/index.php/kerthawicara/article/view/35324/21319, diakses terakhir tanggal 26 November 2020 pada pukul 10.20 Wib. 